\title{
PROGRESSO E DEPRAVAÇÃO: A CULTURA COMO REMÉDIO
}

\author{
Wilson Alves de Paiva* \\ wap@usp.br
}

RESUMO $O$ pensamento iluminista defendia que a ciência e as artes proporcionaram o desenvolvimento da razão e a melhoria dos costumes. A posição contrária, tomada pelo filósofo Jean-Jacques Rousseau (1712-1778), rendeu-lhe o prêmio da Academia de Dijon e o fez, depois da publicação de outras obras, um defensor da natureza e do homem natural. Diante da depravação dos costumes, o autor promove a própria cultura como remédio, haja vista que não se pode voltar ao estado de natureza. O conjunto de sua obra pode, dessa forma, ser considerado como uma tentativa audaciosa de Rousseau em utilizar-se das belas letras (o "Emilio" é um belo exemplo da arte literária do século XVIII) como um remédio contra os males da civilização, principalmente o afastamento do homem para com a natureza.

Palavras-chave Rousseau, Educação, Cultura, Iluminismo.

ABSTRACT The Enlightenment philosophers argued that science and the arts provided the development and improvement of the customs. The contrary position taken by Jean-Jacques Rousseau (1712-1778) produced a great impact so that he received the Dijon Academy Award and was madeafter the publication of other works - a defender of nature and of the natural man. Considering the depravity of manners, the author promotes the culture itself as a remedy, as no one can return to the state of nature. All his writings together can, thus, be seen as a bold attempt to use up the arts ("Emile" is a

\footnotetext{
* Universidade Federal de Goiás (UFG) e Pontifícia Universidade Católica de Goiás (PUC-GO). Artigo recebido em 12/05/2014 e aprovado em 20/01/2015.
} 
fine example of literary art of the eighteenth century) as a remedy against the evil of civilization, mainly the withdrawal of man from nature.

Keywords Rousseau, Education, Culture, Enlightenment.

\section{Introdução}

O Século das Luzes foi altaneiro em relação ao progresso do entendimento humano. A posição que mais caracteriza o pensamento iluminista é a de que a ciência e as artes arrancaram o homem das trevas e propiciaram um mundo de pleno gozo da razão. Isso não quer dizer que os philosophes ignoravam o problema da corrupção moral e da maldade existente nos corações humanos. ${ }^{1}$ Pelo contrário, tinham plena consciência de que o homem de sua época encontrava-se dilacerado e vergado sob a força das contradições. Tomando o exemplo de Diderot, quando reflete sobre a alma do comediante e sua expressão, o paradoxo que ele vivencia pode ser considerado o mesmo do homem social. Vejamos:

No mundo, quando não são bufões, acho-os polidos, cáusticos e frios, faustosos, dissipados, dissipadores interessados, mais impressionados por nosso ridículo do que tocados por nossos males; de um espírito bastante sereno ante o espetáculo de um acontecimento lastimável, ou ante o relato de uma aventura patética; isolados vagabundos, à mercê dos grandes; poucos modos, nenhum amigo, quase sem nenhuma dessas santas e doces ligações que nos associam às penas e aos prazeres de outrem que partilha dos nossos. Vi muitas vezes um comediante rir fora do palco, não guardo lembrança de jamais ter visto um deles chorar. Essa sensibilidade a que eles se arrogam e que se lhes abona, o que fazem dela, então? Largam-na sobre o tablado, quando descem, a fim de retomá-la quando tornam a subir? (Diderot, 2005, p. 254).

Seria a "aventura patética" o mesmo que o sucessivo progresso da desigualdade, relatado por Rousseau no "Segundo Discurso"? Afinal, o "homem policiado" de Rousseau pode ser visto como o comediante que, "sempre fora de si, só sabe viver baseando-se na opinião dos outros e chega ao sentimento de sua própria existência quase que somente pelo julgamento destes" ("Segundo discurso", 1999a, p. 115). ${ }^{2}$ Quase sempre "à mercê dos grandes", o homem policiado "corteja os grandes, que odeia, e os ricos, que

1 Nas palavras de Voltaire: "Confessemos a existência do mal sem acrescentar ainda aos horrores da vida a absurda complacência de negá-lo" (apud Cassirer, 1997, p. 204).

2 As obras de Rousseau serão referenciadas ao longo do texto na ordem "Título, ano, página" e as demais obras na ordem "Autor;", ano, página. Os títulos serão também abreviados. 
despreza; nada poupa para obter a honra de servi-los" (idem). Como bufões, e sem conhecimento de si próprios, os homens sociais, no propósito desta comparação, largam no tablado sua própria sensibilidade e reduzem sua vida às aparências:

Como de uma tal disposição nasce tamanha indiferença pelo bem e pelo mal, com tão belos discursos sobre a moral; como, tudo reduzindo-se às aparências, tudo se torna artificial e representado, seja a honra, a amizade, a virtude, frequentemente mesmo os próprios vícios com os quais por fim se encontra o segredo de se glorificar; como, em uma palavra, perguntando sempre aos outros o que somos e não ousando jamais interrogarmo-nos a nós mesmos sobre esse assunto, em meio a tanta filosofia, humanidade, polidez e máximas sublimes, só temos um exterior enganador e frívolo, honra sem virtude, razão sem sabedoria e prazer sem felicidade. Basta-me ter provado não ser esse, em absoluto, o estado original do homem e que unicamente o espírito da sociedade e a desigualdade, que ela engendra, é que mudam e alteram, desse modo, todas as nossas inclinações naturais (idem).

Porém, para os defensores das luzes, essa realidade não era consequência da iluminação e sim da falta dela. Sem o devido aggiornamento intelectual, o homem mantém alguns laços de seu passado de trevas, como a superstição e as concepções dogmáticas elaboradas pela teologia, que impedem seu pleno desenvolvimento enquanto ser de razão. Ao ler os contos de Voltaire, é possível verificar que, como porta-voz de seu tempo, defendia a ideia comum de que a raiz do mal estava na própria natureza humana, e somente mediante um hedonismo esclarecido a sociedade poderia remediar a situação e aprender a conviver com o mal. No conto "O mundo como está: visão de Babuc, escrita por ele mesmo", 3 o anjo Ituriel visita Babuc e pede-lhe que vá à capital do reino a fim de observar os costumes para decidir sobre a destruição ou preservação daquela cidade. Tão logo chega ao local asseverado, descobre as graves deficiências morais e a depravação daquela sociedade, além de suas virtudes. Contudo, em vez de proferir uma sentença, detém-se a observar e resolve fazer uma estátua a Ituriel. Ao prestar-lhe a homenagem, explica que ela foi feita com diversos metais e pergunta ao anjo se seria capaz de a destruir pelo fato de não ter sido feita somente de ouro ou diamante. $\mathrm{O}$ anjo entende a mensagem e resolve poupar a cidade, deixando-a com suas virtudes e defeitos.

Contrária à posição de Voltaire e dos philosophes, o pensamento de Rousseau vai buscar justamente no homem esclarecido a origem do mal. Na "Carta a Voltaire", ${ }^{4}$ Rousseau escreve: "Não vejo como se possa buscar a fonte 1756. In: "Carta a Christophe de Beaumont", 2005, p. 123. 
do mal moral em outro lugar que não no homem livre, aperfeiçoado, portanto corrompido". A originalidade da solução de Rousseau reside, segundo Cassirer (1997, p. 212 passim), no fato de ter sido o primeiro a transferir o problema do plano da existência individual ao plano da existência social. Então o problema não é da natureza, mas da cultura, da sociedade, da política e do homem artificial, o qual é fruto das relações morais estabelecidas pelo agrupamento e pela socialização. Como diz Rousseau: "Ei-nos no mundo moral, eis a porta aberta ao vício. Com as convenções e os deveres nascem o embuste e a mentira. A partir do momento em que se pode fazer o que não se deve, quer-se esconder o que não se deveria ter feito" ("Emílio", p. 89). Ou seja, a depravação humana só é suscetível de acontecer quando o homem se coloca fora do estado original e adentra o mundo das relações morais. Definitivamente, a maldade não tem raízes na natureza. É preciso repetir com ele a máxima da bondade original, bem expressa no "Emílio" (p. 78): "Ponhamos como máxima incontestável que os primeiros movimentos da natureza são sempre retos: não existe perversidade original no coração humano".

Para entender a posição de Rousseau, é preciso remontar à origem, não apenas para compreender a inexistência do mal, como também para entender o processo que gerou o nascimento da cultura. No entanto, a origem do homem e até mesmo a origem da cultura não podem ser confundidas com a origem do mal. Como veremos mais adiante, vários fatores contribuíram para a ebulição dos sentimentos perniciosos e a degradação moral que acompanhou o estabelecimento da sociedade. Fatalmente a cultura - da forma como foi utilizada - acabou responsável pelos desencontros humanos, pelo progresso das faculdades e pela agitação das paixões. Tendo em vista a fragilidade do estado de natureza, o homem rompeu com a forma solitária e simples de viver, quando não se preocupava com o dia de amanhã e, portanto, não juntava provisões ou lutava pela posse. Ampliou seu modo de vida, desenvolvendo estilos e técnicas, e passou a reclamar o direito sobre outrem (pela força, sedução etc.) ou sobre as coisas, como aconteceu no caso da propriedade privada: alguém que ousou demarcar um pedaço de terra e fez uso da palavra para conclamar: "Isto é meu!" e foi acreditado por seus ouvintes. Usurpação maior não poderia haver, até porque o homem no estado natural não possuía a ideia de teu e meu, isto é, não havia no estado de natureza a ideia de posse e o homem natural não tinha consciência daquilo que porventura viesse a ter, como um animal caçado ou um rústico e provisório abrigo.

Embora efusiva, a declaração de Rousseau, no "Segundo discurso", é seguida de uma explicação de que essas ideias não surgiram repentinamente, mas resultaram de sucessivos acontecimentos até chegar ao ponto no qual o 
desenvolvimento das ciências e das artes depravou os costumes: "Foi preciso fazer-se muitos progressos, adquirir-se muita indústria e luzes, transmiti-las e aumentá-las de geração para geração, antes de chegar a esse último termo do estado de natureza" ("Segundo discurso", p. 87). O lamento de Rousseau é, porém, maior quando observa que em nada as "luzes", a arte e todo o refinamento da civilidade acrescentaram à felicidade humana. Pelo contrário, acabaram por espalhar o luxo, debilitar as virtudes e fomentar o fogo da vaidade e da inveja. Interpretação que afasta Rousseau dos philosophes e do próprio Iluminismo no que diz respeito à exaltação suprema da razão e do progresso do conhecimento humano.

\section{A cultura contra a natureza}

Diante de tudo isso, somos levados a interrogar: seriam, então, o aperfeiçoamento e a reflexão contrários à natureza? Rousseau ousa "quase" afirmar isso: "Se ela [natureza] nos destinou a sermos sãos, ouso quase assegurar que o estado de reflexão é um estado contrário à natureza e que o homem que medita é um animal depravado" ("Segundo discurso", p. 61, grifo nosso). Mas não chega a tanto porque sabe que as primeiras faculdades se desenvolveram para assegurar a própria sobrevivência. Foram esses "fortuitos concursos de circunstância" (ibidem, p. 63) que desenvolveram sua robustez física, bem como a combinação das ideias a ponto de suprir suas necessidades. Mesmo que provavelmente muitos séculos tenham se passado até a descoberta do fogo, a fabricação das armas e o desenvolvimento da linguagem, não quer dizer que essa nova realidade tenha necessariamente engendrado a depravação e a maldade. Mesmo longe do estado original, o homem da "juventude do mundo" (ibidem, p. 93) não possui ainda um grau desenvolvido de reflexão a ponto de ser considerado um ser depravado e corrompido por paixões agitadas, orgulho e maldade, pois conta ainda com sentimentos simples e luzes limitadas. Situação que pode ser comparada a algumas tribos de selvagens para as quais bastavam uma rústica cabana, a família, os recursos alimentares da natureza e as reuniões festivas da comunidade. Como diz Rousseau:

Nada mais meigo do que o homem em seu estado primitivo, quando, colocado pela natureza a igual distância da estupidez dos brutos e das luzes funestas do homem civil, e compelido tanto pelo instinto quanto pela razão a defender-se do mal que o ameaça, é impedido pela piedade natural de fazer mal a alguém sem ser a isso levado por alguma coisa ou mesmo depois de atingido por algum mal (idem).

E logo em seguida afirma: 
Assim, embora os homens se tornassem menos tolerantes e a piedade natural já sofresse certa alteração, esse período de desenvolvimento das faculdades humanas, ocupando uma posição média exata entre a indolência do estado primitivo e a atividade petulante de nosso amor-próprio, deve ter sido a época mais feliz e a mais duradoura (idem).

Entretanto, como uma espécie de vítima da própria criação, o homem sucumbiu ao orgulho nascente: "Aquele que cantava ou dançava melhor, o mais belo, o mais forte, o mais astuto ou o mais eloquente, passou a ser o mais considerado, e foi esse o primeiro passo tanto para a desigualdade quanto para o vício" (ibidem, p. 92). Passando a querer ser visto de uma forma diferenciada, o homem se empenhou em adquirir atributos que lhe colocassem numa posição superior em relação aos demais, de onde nasceram as preferências, a vaidade, a inveja, o desprezo e os demais "germes" funestos à felicidade humana. Até a simples imitação, presente no homem do puro estado de natureza, quando imitava o animal, passou a ser influenciada pelo germe da vaidade ou do desprezo. Fato que preocupa Rousseau no que diz respeito à formação do homem e o leva a refletir, no "Emílio", que a imitação não deve fazer parte das lições de seu aluno, considerando que o bem aparente pode ser menor que o mal que ela pode provocar se suscitar o desejo de transportar-se para fora de si a fim de aparentar, pela imitação, algo que realmente não é:

O homem é imitador, até o animal o é: o gosto da imitação é da natureza bem ordenada; mas degenera em vício na sociedade. O macaco imita o homem que ele teme e não imita os animais que despreza; julga bom o que faz um ser melhor do que ele. Entre nós, ao contrário, nossos arlequins de toda espécie imitam o belo para degradá-lo, para torná-lo ridículo; buscam no sentimento de sua baixeza igualar-se ao que vale mais do que eles; ou, se se esforçam por imitar o que admiram, vemos na escolha dos objetos o falso gosto dos imitadores: querem mais iludir os outros ou fazer com que aplaudam seu talento do que se tornar melhores ou mais sábios. $\mathrm{O}$ alicerce da imitação ente nós está no desejo de nos transportarmos sempre para fora de nós. Se eu tiver êxito na minha empresa, Emílio não terá tal desejo. Cumpre, portanto, que dispensemos o bem aparente que pode produzir ("Emílio", p. 94).

Como vimos, a cisão entre o homem da natureza e o homem do homem foi proporcionada pela própria reflexão. Mas uma reflexão realizada por meio das ideias comparadas e a partir da aparência. Assim, podemos perceber ao longo do processo civilizatório, sobretudo se acompanharmos atentamente a descrição do "Segundo discurso", a preponderância da estética sobre a lógica. Desde os primeiros tempos e as primeiras agregações, quem dançou melhor atraiu para si a atenção dos demais. O belo estava no artifício e na 
diferenciação. A arte ${ }^{5}$ tornou-se rival da natureza e os conceitos de beleza e verdade só puderam ter plena aceitação se resultassem da imaginação e da aparência. $\mathrm{O}$ que se sucedeu à humanidade em nome do progresso da espécie resultou, na visão de Rousseau, no encobrimento da realidade e da verdade por meio de um véu espesso ${ }^{6}$ que encobriu sua verdadeira natureza, gerando uma segunda natureza: "Em uma palavra, explicará como a alma e as paixões humanas, alternando-se insensivelmente, mudam por assim dizer, de natureza" ("Segundo discurso", p. 114).

Até a fala, antes um instrumento de manifestações dos afetos da alma e arte de comunicar os sentimentos, passou a ser a expressão do mal-entendido, da confusão, do engano e da persuasão, obrigado a se transformar em palavras de ordem ou sermão proferido por alguém capaz de persuadir os outros pela camuflagem da retórica. Uma sociedade impura em seus sentimentos e ações só poderia gerar uma linguagem também impura. Aliás, como produto da cultura, e como signo representativo, a linguagem possui em si a propensão para o engano e a mentira, principalmente se for extremamente verbocêntrica e articulada com indecifráveis signos linguísticos, capaz de ser transformada em discurso ${ }^{7}$ que sufoca as falas populares e sua capacidade de manifestação. Infelizmente, "a lamentável facilidade que temos de nos satisfazermos com palavras que não entendemos começa mais cedo do que se pensa", lamenta Rousseau no "Emílio" (p. 53). Daí veio aceitação das primeiras desigualdades e a submissão dos primeiros agrupamentos humanos a uma palavra de ordem proferida por alguém que soube usurpar o poder. Igualmente, a criança é enganada por uma falsa educação travestida de um pretenso refinamento intelectual.

Na Primeira Parte do "Segundo Discurso", Rousseau procura descrever cinco estágios de desenvolvimento pelos quais a humanidade pode ter passado, conforme suas conjeturas. Primeiro, o estado de natureza no qual o homem é um animal robusto, sadio e autônomo em sua constituição física.

5 Rousseau não define o termo, mas o emprega principalmente em dois sentidos: o primeiro remete-se à ideia de criação humana, de artifício, voltada para a produção de um elemento qualquer que auxilie o homem em seu desenvolvimento intelectual. O segundo, presente no "Primeiro discurso" aparece como atividade do espírito, disciplina ou ciência prática, tal como era mais utilizado por outros filósofos. Descartes, por exemplo, dizia no "Discurso do método" (p. 48, grifo nosso): "Quando era mais jovem, eu estudara um pouco de filosofia, de lógica, e, das matemáticas, a análise dos geômetras e a álgebra, três artes ou ciências que pareciam poder contribuir com algo para meu propósito".

6 "Discurso sobre as ciências e as artes", p. 198.

7 "Tudo isso leva à confirmação do princípio que diz deverem todas as línguas escritas, por um progresso natural, mudar de caráter e perder força, ganhando clareza; que quanto mais se procurar aperfeiçoar a gramática e a lógica, mais se acelerará esse progresso; e que, para rapidamente tornar uma língua fria e monótona, basta estabelecer academias no seio do povo que a fala" ("Ensaio sobre a origem das línguas", 1999d, p. 283). 
Os primeiros progressos surgiram devido às dificuldades que lhes oferecia a própria realidade natural que, provavelmente, tenha promovido os primeiros compromissos entre os da mesma espécie. No segundo estágio, a Idade do Ouro, os homens buscaram os lugares mais seguros e o bem-estar segundo as fontes da natureza, desenvolveram características sedentárias, como a habitação, a família e até mesmo uma forma primitiva de propriedade, como a cabana onde habitavam. ${ }^{8}$ Infere-se a partir daí que a linguagem foi necessária para uma melhor comunicação e com ela surgiram o canto, a dança e outras manifestações culturais. ${ }^{9}$ Porém, a agricultura e a metalurgia forçaram a divisão do trabalho, das terras e a imposição da propriedade privada em favorecimento dos ricos e poderosos, gerando um terceiro estágio na linha do desenvolvimento humano cuja sociedade tem um quadro de perversão moral e corrupção social. Um quarto estágio coloca em destaque o sentido paradoxal da palavra "progresso", uma vez que é a desigualdade que se amplia nas leis e nas instituições estabelecidas em grande parte para beneficiar os poderosos. E estes, por sua vez, passaram a contar com a conivência e o beneplácito dos magistrados, os quais não atendiam às necessidades do povo ${ }^{10} \mathrm{em}$ geral e sim

8 "Os primeiros progressos do coração resultaram de uma situação nova que reunia numa habitação comum os maridos e as mulheres, os pais e os filhos. O hábito de viver junto fez com que nascessem os mais doces sentimentos que são conhecidos do homem, como o amor conjugal e o amor paterno. Cada família tornou-se uma pequena sociedade, ainda mais unida por serem a afeição recíproca e a liberdade os únicos liames e, então, se estabeleceu a primeira diferença no modo de viver dos dois sexos, que até aí nenhuma apresentavam. As mulheres tornaram-se mais sedentárias e acostumaram-se a tomar conta da cabana e dos filhos, enquanto homens iam procurar a subsistência comum. Os dois sexos começaram, assim, por uma via um pouco mais suave, a perder alguma coisa de sua ferocidade e de seu vigor. Mas, se cada um em separado tornou-se menos capaz de combater as bestas selvagens, em compensação foi mais fácil reunirem-se para resistirem em comum" ("Segundo discurso", 1999a, pp. 90-91).

9 "Quando as ideias dos homens começaram a estender-se e a multiplicar-se, e se estabeleceu entre eles uma comunicação mais íntima, procuraram sinais mais numerosos e uma língua mais extensa" (ibidem, p. 71).

10 A palavra "povo" tem vários significados. Segundo Chartier (1988, pp. 192-193), "As definições da palavra 'povo' nos dicionários de língua do século XVIII, que indicam as acepções mais comuns. Atestam esse corte, muitas vezes pensando através da oposição feita pelo latim entre populus e plebs. Como por exemplo no Dictionnaire de Trévoux, na sua edição de 1771: 'Povo. Esta palavra significa frequentemente a parte menos considerada de entre os habitantes... Assim, há uma grande diferença entre a palavra francesa povo e a palavra latina populus. Nesta acepção, quer dizer aquilo a que os romanos chamavam de plebs. Há muito povo no bairro dos Halles. Neste sentido, corresponde a povinho, a povo miúdo, isto é, à arraia-miúda. Utiliza-se o termo mais ou menos no mesmo sentido por oposição aos que são nobres, ricos ou esclarecidos'. Assim definido por defeito (de nascimento, de fortuna ou de instrução), o povoplebs não pode ser considerado como um sujeito político. Furetière, em 1727, caracteriza-o do seguinte modo, através de lugares-comuns: 'o povo é povo em todo o lado, isto é, tonto remexido, amante das novidades. $\mathrm{O}$ povo tem o costume de odiar nos outros as mesmas qualidades que neles admira; tudo o que está para além das suas regras ofende-o, e sofreria mais facilmente um vício comum do que uma virtude extraordinária, segundo Voltaire. [...] No dicionário de Richelet, inalterado desde a primeira edição de 1680: 'O povinho. É toda a ralé de uma cidade. É tudo o que há de gentes que não são de qualidade, nem burgueses desafogados, nem aquilo a que se chama pessoas honestas".

Para a maioria dos escritos dessa época, o povo e a cultura popular, eram desprovidos do elemento político e nada ofereciam de bom. O pensamento de Rousseau destoa dessas afirmações e concede 
às determinações das autoridades despóticas. $\mathrm{O}$ que conduziu a sociedade ao último estágio, o do despotismo, no qual a análise de Rousseau se aproxima da de Hobbes quanto ao estado de guerra generalizado que coloca em perigo a própria sobrevivência da humanidade.

\begin{abstract}
Assim, os mais poderosos ou os mais miseráveis, fazendo de suas forças ou de suas necessidades uma espécie de direito ao bem alheio, equivalente, segundo eles, ao de propriedade, seguiu-se à rompida igualdade a pior desordem; assim as usurpações dos ricos, as extorsões dos pobres, as paixões desenfreadas de todos, abafado a piedade natural e a voz ainda fraca da justiça, tornaram os homens avaros, ambiciosos e maus. Ergueu-se entre o direito do mais forte e o do primeiro ocupante um conflito perpétuo que terminava em combates e assassinatos. A sociedade nascente foi colocada no mais tremendo estado de guerra; o gênero humano, aviltado e desolado, não podendo mais voltar sobre seus passos nem renunciar às aquisições infelizes que realizara, ficou às portas da ruína por não trabalhar senão para sua vergonha, abusando das faculdades que o dignificam (“Segundo discurso”, 1999a, p. 98).
\end{abstract}

Até o final do estado de natureza e o início da Idade do Ouro, os encontros furtivos e os primeiros artifícios não foram suficientes para colocar em risco a espécie, porque as paixões não haviam sido ainda inflamadas e nem o poder usurpado em benefício de alguns e em detrimento de outros. $\mathrm{Na}$ evolução natural do homem e no progresso fomentado pelas primeiras necessidades, o processo de agregação e até mesmo de sedentarização inicial tinha ainda a bondade original e a compaixão como os únicos elementos legitimadores dos encontros. Comentando sobre a origem das primeiras sociedades e das línguas nas regiões quentes, Rousseau diz que:

\begin{abstract}
Aí se formaram os primeiros laços de família e aí se deram os primeiros encontros entre os dois sexos. As moças vinham procurar água para casa, os moços para dar de beber aos rebanhos. Olhos habituados desde a infância aos mesmos objetos, começaram aí a ver outras coisas mais agradáveis. O coração emocionou-se com esses novos objetos, uma atração desconhecida tornou-o menos selvagem, experimentou o prazer de não estar só. A água, insensivelmente, tornou-se mais necessária, o gado teve sede mais vezes: chegava-se açodadamente e partia-se com tristeza. Nessa época feliz, na qual nada assinalava as horas, nada obrigava a contá-las, e o tempo não possuía outra medida além da distração e do tédio. Sob velhos carvalhos, vencedores dos anos, uma juventude ardente aos poucos esqueceu a ferocidade. Acostumaram-se gradativamente uns aos outros e, esforçando-se por fazer entender-se, aprenderam
\end{abstract}

ao termo um novo sentido. Pelo que diz no "Contrato social" (p. 68): "um povo é povo antes de dar-se a um rei", podemos depreender que para ele povo são os homens em geral, possuidores das mesmas qualidades humanas. Mais do que isso, dentro do pacto o povo é o conjunto dos componentes de um corpo político. Quando Rousseau ("Segundo discurso", p. 80, grifo nosso) fala que "os caraíbas, que são o povo que até agora menos se distanciou do estado de natureza...", está se referindo à nação nativa dos caraíbas, bem definida por seus laços étnicos e culturais. Em todos os casos, não há uma conotação pejorativa, como foi citado acima por Chartier. 
a explicar-se. Aí se deram as primeiras festas - os pés saltavam de alegria, o gesto ardoroso não bastava e a voz o acompanhava com acentuações apaixonadas; o prazer e o desejo confundidos faziam-se sentir ao mesmo tempo. Tal foi, enfim, o verdadeiro berço dos povos - do puro cristal das fontes saíram as primeiras chamas do amor ("Ensaio sobre a origem das línguas", 1999d, p. 297).

O trecho acima citado, resume a condição pré-social menos deteriorada possível. Até porque essa organização comunitária nascente não pode ser contrária à natureza, uma vez que ainda não desenvolveu totalmente a reflexão e a arte de transformar tanto as disposições naturais como a si mesmo. $\mathrm{O}$ pathos sociocultural é gerado precisamente quando o amor a si mesmo se torna o amor-próprio, ou seja, quando o homem passa a ter a consciência e o orgulho de sua superioridade, ${ }^{11}$ deixando que a vaidade tome seu coração. A partir daí, o homem procura ser melhor na caça, na pesca, na luta e em todas as ações que possam destacá-lo dos demais, colocando-o em posição vantajosa para sua própria pessoa e não mais para a comunidade. Nesse ponto, o amorpróprio é agressivo, controlador e dissimulador porque passa a reivindicar um reconhecimento diferenciado perante os outros, um prestígio pessoal que possa, na maioria dos casos, render glória e poder. À medida que os sentimentos se multiplicam, o que é mera distração e lazer, como as reuniões em torno de uma fogueira diante das cabanas, a entoação dos cânticos e a realização das danças, passa a ser espetáculo e fermentação dos sentimentos torpes como a inveja, a vaidade e outros semelhantes.

Sobre o nascimento dos vícios, nesse contexto, Rousseau afirma que:

Cada um começou a olhar os outros e a desejar ser ele próprio olhado, passando assim a estima pública a ter um preço. Aquele que cantava ou dançava melhor, o mais belo, o mais forte, o mais astuto ou o mais eloquente, passou a ser o mais considerado, e foi esse o primeiro passo tanto para a desigualdade quanto para o vício; dessas primeiras preferências nasceram, de um lado, a vaidade e o desprezo, e, de outro, a vergonha e a inveja. A fermentação determinada por esses novos germes produziu, por fim, compostos funestos à felicidade e à inocência ("Segundo discurso", 1999a, p. 92).

Por isso Rousseau tornou-se um enfático crítico do progresso. ${ }^{12}$ Embora julgando indispensável louvar o restabelecimento das ciências e das artes, talvez para agradar os membros da Academia ou para sinalizar

11 "Assim, o primeiro olhar que lançou sobre si mesmo produziu-lhe o primeiro movimento de orgulho" ("Segundo discurso", 1999a, p. 89).

12 Pissarra (1996, p. 165) diz que: "Ao se opor aos defensores do luxo e da teoria do progresso que ela representava, Rousseau fez duras críticas principalmente a Mandeville e a Voltaire, por julgar que o luxo não pode ser discutido à luz da questão da justiça, ou seja, o resultado da sua existência é a desigualdade, não podendo nunca o bem resultar do vício". 
que não defenderia a supressão delas, o autor não nos deixa esquecer que o desenvolvimento dessas capacidades e talentos humanos se deve à vaidade. ${ }^{13}$ Por ela, no sentido de implementar os gostos, as preferências e os costumes, o refinamento acabou criando um mundo de aparências, engano e corrupção. "Não se ousa parecer mais tal como se é" (ibidem, p. 192), porque, tendo se afastado do feliz estágio de ignorância que a Natureza propiciou, os homens usaram de sua capacidade criativa e seu gosto estético para criar uma teia de representações fúteis e ilusórias. O hedonismo e a luxúria ao qual se lançaram produziram na mentalidade humana um embotamento moral a ponto de não se desejar mais a virtude: "Tornando-se sociável e escravo, torna-se fraco, medroso e subserviente, e sua maneira de viver, frouxa e afeminada, acaba por debilitar ao mesmo tempo sua força e sua coragem" "'Segundo discurso", 1999a, p. 62). Debilidade que Rousseau observa em todos os aspectos da vida, principalmente no que diz respeito às qualidades morais, ao julgamento e até à aprendizagem:

Se a cultura das ciências é prejudicial às qualidades guerreiras, ainda o é mais às qualidades morais. Já desde os primeiros anos, uma educação insensata orna nosso espírito e corrompe nosso julgamento. Vejo em todos os lugares estabelecimentos imensos onde a alto preço se educa a juventude para aprender todas as coisas, exceto seus deveres. Vossos filhos ignoram a própria língua, mas falarão outras que em lugar algum se usam; saberão compor versos que dificilmente compreenderão; sem saber distinguir o erro da verdade, possuirão a arte de torná-los ambos irreconhecíveis aos outros, graças a argumentos especiosos; mas não saberão o que são as palavras magnanimidade, equidade, temperança, humanidade e coragem; nunca lhes atingirá o ouvido a doce palavra pátria e, se ouvem falar de Deus, será menos para reverenciálo do que para temê-lo. Preferiria, dizia um sábio, que meu aluno tivesse passado o tempo jogando péla, pois pelo menos o corpo estaria mais bem-disposto. Sei que é preciso ocupar as crianças e que a ociosidade constitui para elas o maior dos perigos a evitar. Que deverão, pois, aprender? Eis uma questão interessante. Que aprendam o que devem fazer sendo homens e não o que devem esquecer ("Discurso sobre as ciências e as artes", 1999b, p. 209).

Nisso, a evolução da humanidade pode ser analisada em analogia à evolução da criança. Toda a análise de Rousseau em torno do aperfeiçoamento, do progresso e das virtudes humanas pode ser vista perpendicularmente com a tarefa educativa da infância e a formação geral do homem. Por isso, no "Emílio" vamos encontrar as cinco etapas ou estágios evolutivos do fenômeno educativo: A primeira etapa da idade da natureza, que corresponde ao Livro vaidade tornou alguém feliz na terra, infalivelmente esse feliz era apenas um tolo". 
I e aos dois primeiros anos de vida da criança, favorece a liberdade e os primeiros movimentos físicos; nele, a relação com mãe é direta e constante. O estágio seguinte, a segunda etapa da idade da natureza, que corresponde ao Livro II do "Emílio" e vai dos dois aos doze anos, a criança desenvolve a fala e outras habilidades sensitivas que levam ao fim da infância. No Livro III, a terceira etapa, a idade da força, as paixões afloram entre os doze e os quinze anos e a educação deve proporcionar experiências úteis ao desenvolvimento de seu raciocínio. Mas é na etapa seguinte, a idade da razão e das paixões, Livro IV, que vai dos quinze aos vinte anos, que os princípios da sociabilidade devem ser desenvolvidos com maior ênfase, a fim de educar as paixões e o amor próprio. E no último estágio, que corresponde ao Livro $\mathrm{V}$ e à idade adulta, Rousseau trata do matrimônio, ou seja, da formação da família, que é, segundo ele, a primeira instituição social.

Como baluartes da cultura, as instituições sociais desnaturam o homem e configuram os traços de uma nova natureza. E o diferencial das boas instituições é justamente a forma como desnaturam o homem e encaminham o processo cultural com vistas à melhor adaptação desse homem à vida coletiva (Cf. "Emílio", p. 13).

\section{0 disfarce da civilidade e a cultura como remédio}

A cultura pode ser entendida como um avanço do entendimento humano e uma notável capacidade de aperfeiçoamento das habilidades técnicas e intelectuais. Entretanto, aprendemos com Rousseau que, em vez de ter promovido uma desnaturação virtuosa e uma verdadeira civilidade, o processo cultural significou a reificação do homem e seu afastamento da natureza. Tal afastamento foi inversamente proporcional ao progresso das artes, das ciências, da linguagem e do entendimento em geral. Essencialmente representativa, a cultura criou símbolos, imagens e ícones que acentuaram esse afastamento e foram utilizados para falsificar a realidade e mover os costumes rumo à valorização da aparência. Como diz Rousseau: "Para proveito próprio, foi preciso mostrar-se diferente do que na realidade se era" ("Segundo discurso", p. 97), ou seja, foi preciso criar uma representação imaginária, um disfarce, a fim de engrandecer-se e promover sua própria aparência, pois tinha mais valor quem soubesse combinar esses signos de forma que se destacasse dos demais, seja pelo luxo, seja pela melhor articulação da linguagem ou pelos diversos artifícios representativos.

Com isso, a moralidade tornou-se, por assim dizer, serva da teatralização, isto é, do espetáculo. Edificada na lógica da apresentação e da representação, 
a vida social teve, na verdade, sua estrutura trincada pela dicotomia entre ser e parecer ${ }^{14}$ de tal forma que as relações humanas adentraram a opacidade do teatro, cujo valor está na capacidade de dissimular, representar e utilizar ao máximo suas máscaras. Assim, despido da natureza, o homem buscou compensar sua perda com a indumentária de uma civilidade enganosa, vestindo a fantasia do orgulho, do luxo, e mascarando-se com toda criação artística que pudesse esconder sua real aparência e promover uma falsa realidade, um teatro ilusório e faustoso.

O disfarce da civilidade ${ }^{15}$ serve, nesse aspecto, para encobrir as características originais do homem. E, tomando a sociedade espetacular do século XVIII, podemos dizer que não se trata de simples disfarce, mas de fantasia - o que Rousseau chama de "fausto majestoso" ("Segundo discurso", p. 97) -, uma vez que a artificialização deve ser alimentada pelo sonho e pelo desejo de transportar-se para fora de si mesmo e impor uma aparência enganosa. E o espetáculo é somente isso: uma fantasia, um divertimento ilusório e aparentemente sem utilidade e sem proveito para com a promoção das virtudes, uma vez que comove pela aparência e não pela realidade. Afinal, como diz em nota de rodapé, no "Ensaio sobre a origem das línguas" (p. 262, nota 1), "as infelicidades fingidas nos tocam bem mais do que as verdadeiras. Uma pessoa pode soluçar ouvindo uma tragédia e nunca, durante toda a vida, sentir piedade de um infeliz". E na mesma nota critica os philosophes e todos os defensores da tragédia como um instrumento pedagógico que pudesse causar um efeito catártico no público: "O teatro se presta admiravelmente para enobrecer nosso amor-próprio com todas as virtudes que não possuímos".

$\mathrm{O}$ argumento defendido por muitos dos pensadores iluministas, isto é, o de que o teatro poderia produzir uma catarse, não foi suficiente para convencer Rousseau. Pelo contrário, serviria para acentuar a representação, aumentar o desejo pelo espetáculo e alimentar as paixões no desenvolvimento do amorpróprio. Entretanto, seu posicionamento contrário não fez dele um inimigo das artes, mas alguém que soube utilizar-se delas para atacar seu efeito devastador. Ou seja, como um princípio ativo de um remédio, as artes podem ser utilizadas para o malefício ou a cura dos males.

14 Como nos lembra Salinas Fortes (1997, p. 25), "A análise da vida social segundo o esquema ser/parecer é central em Rousseau, desde o primeiro Discurso".

15 Em seu livro "As máscaras da civilização", Starobinski (2001, p. 12) cita o significado do termo civilização, de onde deriva civilidade, a partir do "Novo dicionário francês contendo novas criações do povo francês", de Göttingen, de 1795: "Essa palavra, que esteve em uso apenas na prática, para dizer que uma causa criminal é tornada civil, é empregada para exprimir a ação de civilizar ou a tendência de um povo a polir, ou, antes, a corrigir seus costumes e seus usos produzindo na sociedade civil uma moralidade luminosa, ativa, afetuosa e abundante em boas obras". 
Além de ter escrito algumas óperas, Rousseau foi autor da peça "Narciso, ou o amante de si mesmo", na qual procura demonstrar que o efeito catártico é ilusório. Para ele, a capacidade de se pôr no lugar do outro deve ser real e não apenas imitativa. Se essa transposição é feita de forma apenas imaginária, no âmbito do teatro, acaba-se por fazer como Narciso, o qual usurpou o lugar do outro somente pelo prazer de viver a personagem. Mas no Prefácio da obra Rousseau coloca uma nota contra a desesperança que tais afirmações possam gerar, fazendo-nos lembrar que a aparência bem intencionada pode conter virtude. Principalmente a afirmação de que um povo uma vez corrompido nunca mais volta à virtude. Quanto a isso Rousseau faz um comentário no prefácio da comédia "Narciso ou o amante de si mesmo" que deixa clara a importância pedagógica das ciências e das artes e o papel que a educação tem na preparação das gerações futuras:

Mas, quando um povo já se corrompeu até um certo ponto, quer as ciências tenham, quer não, contribuído para tanto, será preciso bani-las ou se preservar delas para torná-lo melhor ou impedi-lo de tornar-se ainda pior? Esta é outra questão, em relação à qual me declarei positivamente pela negativa. Pois, em primeiro lugar, uma vez que um povo corrupto nunca mais volta à virtude, não se trata de tornar bons aqueles que não o são, mas de conservar assim aqueles que têm a felicidade de sê-lo. Em segundo lugar, as mesmas causas que corromperam os povos servem algumas vezes para prevenir uma corrupção maior (Rousseau, 1999a, p. 300). ${ }^{16}$

Nesse aspecto, o mal contém seu remédio ${ }^{17}$ na medida em que for utilizado para evitar um mal pior, como um antídoto, em benefício público. Até porque, como diz a referida nota (nota 2 da mesma página):

Esse simulacro consiste numa certa doçura de costumes que algumas vezes substitui sua pureza, uma certa aparência de ordem que previne a tremenda confusão, uma certa admiração pelas belas coisas que impede as boas de caírem inteiramente no esquecimento. É o vício que toma a máscara da virtude, não como a hipocrisia para enganar e trair, mas para, sob essa efígie amável e sagrada, afastar o horror que tem de si mesmo quando se contempla nu (ibidem, p. 300).

Mesmo que Rousseau não admita abertamente uma relação de causa e efeito entre as ciências e as artes e a depravação humana, essa ideia fica mais clara quando engloba todos os progressos culturais com o desenvolvimento da desigualdade, no "Segundo discurso". Apesar de tudo, o autor reconhece

16 Aqui preversei a ordem "Autor", ano e página porque o "prefácio" está no mesmo volume (II) da coleção Rousseau, da Nova Cultural.

17 Como diz Starobinski (2001, p. 179), em Rousseau, "é a natureza que oferece o remédio do mal, ou então é a arte aperfeiçoada". 
a utilidade que as artes têm na implementação da vida cotidiana. Na "Última resposta ao Sr. Bordes", uma das diversas refutações aos ataques recebidos pelo "Discursos sobre as ciências e as artes", publicada no "Mercure de France", diz que:

As ciências são a obra-prima do gênio e da razão. O espírito de imitação produziu as belas-artes, e a experiência as aperfeiçoou. Devemos às artes mecânicas um grande número de invenções úteis que aumentaram os encantos e as comodidades da vida. Eis verdades com as quais de bom grado concordo (ibidem, p. 262).

Até porque, ao continuar em suas refutações, Rousseau toma um partido inusitado para os leitores de seu século, mas bastante compreensível para os dias de hoje. Apesar de ter atacado o desenvolvimento da cultura, não quis dizer que devessem, pois, destruir as bibliotecas, as academias, os colégios, as universidades e até mesmo os espetáculos (ibidem, pp. 300/301). Pois, como diz no "Emílio" (p. 134), "a descoberta da causa do mal indica o remédio". De onde podemos inferir que essas manifestações artísticas bem encaminhadas podem evitar a ociosidade e ser bem utilizadas com o propósito de infundir nas mentalidades a virtude necessária ao pleno desenvolvimento do homem em suas disposições civis, bem como em suas necessidades pessoais. Provavelmente influenciada por Platão, essa perspectiva se reveste de uma finalidade pedagógica com vistas a evitar a corrupção e a redirecionar o labor artístico no sentido de melhor conduzir o desenvolvimento das paixões e bem encaminhar as emoções.

Então o sentido de arte pode ser mudado para uma perspectiva benéfica se for entendida como ação humana que, em vez de alimentar as paixões, consiga atuar no silêncio delas, objetivando o belo e o verdadeiro na plenitude humana. Tal compreensão leva-nos a refletir, como fez Nunes (2000, p. 10), que o pensamento dos séculos XVII e XVIII tinha um conceito de "arte como aquele produto da atividade humana que, obedecendo a determinados princípios, tem por fim produzir artificialmente os múltiplos aspectos de uma só beleza universal, apanágio das coisas naturais".

Rousseau encarna essa ideia com muita paixão e, ciente da utilidade das artes, encerra suas refutações dizendo:

Esperando, escreverei livros, comporei versos e música, caso tenha para isso talento, tempo, força e vontade, e continuarei a dizer, com toda a franqueza, todo o mal que penso das letras e daqueles que as cultivam, tendo certeza de não valer menos por isso. É verdade que um dia poderão dizer: 'Esse inimigo tão declarado das ciências e das artes, todavia, fez e publicou peças de teatro', e tal discurso constituirá, confesso, uma sátira muito amarga, não a mim, mas a meu século ("Discurso sobre as ciências e as artes", 1999b, p. 302). 
Essa posição um tanto quanto gauche ${ }^{18}$ foi exatamente o diferencial de Rousseau em relação à produção intelectual de seu século, mais precisamente dos philosophes que em sua maioria louvavam incondicionalmente o progresso das artes e das ciências, bem como seu valor para com os costumes em geral.

A realidade é que os homens se aperfeiçoaram, desenvolveram suas habilidades ampliando cada vez mais suas ideias e sua imaginação. Com o agrupamento, diversas características sociais, como a língua, a família, as regras morais, as leis e a política compuseram o grande artifício humano ao qual chamamos sociedade. O progresso retirou o homem de suas condições primitivas, nas quais vivia livre e feliz, mas não conseguiu promover a liberdade e a felicidade no contexto do estado civil. Pelo contrário, a produção cultural, em todas as suas manifestações, voltou-se contra as origens e rompeu o lastro que alimentava a natureza humana. Sem a voz da Natureza e os traços originais desta, as novas condições traduziam o desvario do homem e sua perda: "Tudo não é senão loucura e contradição nas instituições humanas" ("Emílio", p. 65).

Diante de um quadro tão desolador, o que fazer? Se Rousseau não foi um revolucionário, colocando a mão na massa, pelos menos colocou a mão na pena ("Emílio", p. 27) e registrou seu grito de revolta, sua denúncia e seu protesto que resultou numa coletânea de reflexões e observações sobre a formação humana, intitulada "Emílio ou da educação". Por tudo que ele contém, seu tratado pode ser entendido como uma obra de arte que a educação pode promover, tomando o homem em sua realidade e preparando-o para as mais adversas situações e condições de vida. Uma tentativa audaciosa de Rousseau em utilizar-se das belas letras (uma vez que "Emílio" é um belo exemplo da arte literária do século XVIII) como um remédio contra os males da civilização, principalmente o afastamento do homem em relação à natureza.

Em que sentido a obra é um remédio? Basicamente no sentido da aquisição cultural e na ampliação das possibilidades humanas de uma forma nova, distinta da realidade dada, que possibilite a plena realização do homem em sua verdadeira natureza. Vemos que, do início ao fim do "Emílio", a criança é preparada para desenvolver sua sensibilidade, suas disposições naturais e suas possibilidades criativas (para si e para os outros) para, ao fim, tornar-se o homem pleno, preparado para viver em qualquer sociedade sem se corromper.

18 Lembrando do termo utilizado pelo poeta Carlos Drummond de Andrade em seu "Poema de sete faces", que diz: "Quando nasci, um anjo torto/desses que vivem na sombra/disse: Vai, Carlos! Ser gauche na vida". O que nos faz lembrar o polêmico pai de Rousseau (anjo torto) influenciando seu filho nas leituras filosóficas e nas quase intermináveis discussões literárias, descritas nas "Confissões". 
Um exemplo disso está na sequência do Livro V do "Emílio", que é a obra "Emílio e Sofia", no qual o autor relata as desventuras do casal. Malgrado toda adversidade enfrentada, tais como a infidelidade de Sofia, a perda da filha, o ambiente parisiense, e toda espécie de sofrimento, Emílio permaneceu firme nos princípios da bondade e da virtude. Mesmo sob a condição de escravo, na Argélia, seu caráter permaneceu inflexível e soube tirar proveito quando, mesmo tratado brutalmente, animou seus companheiros e persuadiu o amo de que os escravos trabalhariam melhor se fossem bem tratados. "Sabemos carregar o jugo da necessidade" (Rousseau, 1994, p. 239), argumentou Emílio ao tentar convencer o patrão de suas boas intenções.

Por que Emílio teve que sofrer tanto? Propósito de Rousseau? Fatalidade da vida? Em busca de uma resposta, presumimos que a intenção de Rousseau, expressa no início do "Emílio" (p. 16), era a de generalizar os pontos de vista e considerar no aluno "o homem exposto a todos os acidentes da vida humana" de maneira que pudesse desenvolver nele o próprio instinto de conservação e adaptação às circunstâncias gerais. Também, talvez Rousseau quisesse demonstrar que, embora toda a arte possa ser empregada no processo educacional, o resultado é realmente indeterminado, como afirmara no início de seu tratado (p. 11), tendo em vista a dura realidade da existência humana. Porém, com a sorte desejada, é possível que a ação educativa consiga aproximar-se da meta, que não é outra senão "a própria meta da natureza" (idem), logrando a formação do homem - o que vive de acordo consigo mesmo e livre do julgo das paixões. Nas palavras do desventurado Emílio, foi exatamente isso o que o preceptor lhe ensinara:

Não podendo, então, me proteger de todos os laços que nos atam às coisas, você me ensinou a, ao menos, escolhê-los, a abrir a minha alma apenas aos mais nobres, a não ligá-la senão aos mais dignos objetos que são meus semelhantes, a estender por assim dizer, o eu humano sobre toda a humanidade, e a me preservar assim das vis paixões que o restringem ("Emile e Sophie ou os solitários", 1994, p. 23).

Assim, diante de uma realidade na qual o homem se encontra desfigurado e as instituições públicas corrompidas, ${ }^{19}$ o que resta fazer é empreender a educação doméstica, aquela que evoca a primazia da natureza e forma tão somente o indivíduo, sem pressupor uma formação cívica. Mas, continua ele interrogando, "o que será para os outros um homem unicamente educado para si mesmo?" (ibidem, p. 15). O que vai adiantar essa "primazia da natureza" se pode mais existir, porque não há mais pátria, não pode haver cidadãos" (“Emílio", p. 14). 
esse homem se encontra na ordem civil? Portanto, mais uma vez vale citar o desejo de superação presente nas palavras do autor: "Se o duplo objetivo que se propõe pudesse porventura reunir-se num só, eliminando as contradições do homem, eliminar-se-ia um grande obstáculo à sua felicidade" (idem). ${ }^{20}$ Uma junção da educação possível: a da natureza, com a educação desejada: a pública. E, enquanto não houver "pátria" e "cidadão" nos termos que Rousseau os entende, ${ }^{21}$ é possível ir construindo a rota, formando o homem em toda sua interioridade e renovando os traços de sua exterioridade, a fim de que resista às opiniões dos homens, que resista às tendências e à moda. Isto significa, nos termos que utilizamos neste trabalho, o homem reconfigurado, uma vez que seu modo de ser, na resistência e na posição contrária à opinião pública e as tendências gerais da sociedade depravada, dar-lhe-á uma identidade cujos traços serão distintos das características do homem primitivo, bem como das do homem civil à sua frente. Mais ainda, o homem no sentido pleno da palavra, ${ }^{22}$ ou seja, aquele que mesmo jogado ao "turbilhão social" ("Emílio", p. 286) das sociedades existentes, consiga ter domínio de si e não se submeta aos ditames das paixões e nem às opiniões dos homens. Enfim, o homem que se torna social de forma virtuosa - utilizando os recursos culturais - sem deixar para trás suas qualidades naturais.

Dessa forma, contra o disfarce de uma civilidade doentia, a formação humana como Rousseau a concebe deve ser vista como um bálsamo cujas propriedades terapêuticas podem contribuir com a recuperação de um homem desvirtuado e com a restauração de sua real figura. Em outros termos, a obra é uma grande pedagogia que nos ensina a melhor forma de conduzir o homem pelas vias do engrandecimento de sua interioridade e pelos caminhos do mais virtuoso relacionamento com as coisas e com os semelhantes. Por isso, em nossa opinião, o "Emílio" destaca-se, dentre os escritos rousseaunianos, como

20 Muito esclarecedor o texto de Francisco (2008) sobre o tema. Quanto ao trecho citado, diz a autora: "Essas palavras, talvez as mais importantes de toda a parte inicial do Emilio acerca dos princípios que governam a educação humana, expõe claramente o propósito maior do autor na obra: trata-se não de formar apenas o homem natural, o indivíduo, o ser da casa e da pequena sociedade da família, mas de buscar, na mesma medida, formar o cidadão, o homem social, o ser da sociedade stricto sensu. É evidente, portanto, que o Emílio não pode ser simplesmente lido como uma obra de educação doméstica, de formação do homem natural. Há aí, sem dúvida alguma, a intenção de formá-lo. Mas, há, igualmente, por outro lado, a intenção de encontrar as vias para se chegar ao cidadão. Entretanto, mais do que tudo, o que se pretende é dar solução à contradição do homem, isto é, formá-lo não homem natural ou cidadão e sim, homem natural e cidadão" (p. 61).

21 Legitimados por um pacto nos moldes do "Contrato social", ou pelo menos numa nação onde o povo seja soberano (direta ou indiretamente) e haja uma educação voltada para os ideais cívicos, como aparece nas "Considerações sobre o governo da Polônia".

22 Cf. Derathé (1984, p. 111). 
a mais sublime declaração de amor ao gênero humano que alguém jamais pôde escrever.

\section{Referências}

CASSIRER, E. "A filosofia do Iluminismo". Tradução: Álvaro Cabral. $3^{\mathrm{a}}$ ed. Campinas/SP: Ed. UNICAMP, 1997.

CHARTIER, R. "A história cultural: entre práticas e representações". Trad. Maria Manuella Galhardo. Lisboa: DIFEL; Rio de Janeiro: Bertrand Brasil, 1988.

DERATHÉ, R. "L'homme selon Rousseau". In: BENICHOU, P. et al. Pensée Rousseau. Paris: Éditions du Seuil, 1984.

DESCARTES, R. "Discurso do método e outras obras". Coleção Os Pensadores. São Paulo: Nova Cultural, 2004.

DIDEROT, D. "Paradoxo sobre o comediante". In: DIDEROT. Coleção Os Pensadores. São Paulo: Nova Cultural, 2005.

FRANCISCO, M. F. S. "Notas acerca da Educação Doméstica e Educação Pública no Emílio de Rousseau". In: Notandum 16. Porto: ESDC/CEMOrOC-Feusp/IJIUniversidade do Porto, 2008.

NUNES, B. "Introdução à filosofia da arte". São Paulo: Ática, 2000.

. "Carta a Christophe de Beaumont e outros escritos sobre a religião e a moral". Organização e apresentação, José Oscar de Almeida Marques; Tradução, J. O. Q. M. et al. São Paulo: Estação Liberdade, 2005.

PISSARRA, M. C. P. P. "História e ética no pensamento de Jean-Jacques Rousseau". São Paulo: Universidade de São Paulo, 1996. (Tese de Doutorado).

ROUSSEAU, J.-J. "As confissões" (2 Vol.). Trad. Rachel de Queiroz. 2a ed. São Paulo: Atena, 1959.

. "Emílio ou da educação". $2^{a}$ ed. São Paulo: Difusão Europeia do Livro, 1973.

. "Emile e Sophie ou os solitários". Edição bilíngue (francês e português).

Trad. Dorothée de Bruchard. Porto Alegre: Paraula, 1994.

. "Discurso sobre a origem e os fundamentos da desigualdade entre os homens".

Tradução de Lourdes Santos Machado. Introduções e notas de Paul Arbousse-Bastide e Lourival Gomes Machado. S. Paulo: Nova Cultural, 1999a. (Coleção Os Pensadores; Vol. II).

. "Discurso sobre as ciências e as artes". Tradução de Lourdes Santos Machado. Introduções e notas de Paul Arbousse-Bastide e Lourival Gomes Machado. S. Paulo: Nova Cultural, 1999b. (Coleção Os Pensadores; Vol. II).

. "Do contrato social". Tradução de Lourdes Santos Machado. Introduções e notas de Paul Arbousse-Bastide e Lourival Gomes Machado. S. Paulo: Nova Cultural, 1999c. (Coleção Os Pensadores; Vol. I).

. "Ensaio sobre a origem das línguas". Tradução de Lourdes Santos Machado.

Introduções e notas de Paul Arbousse-Bastide e Lourival Gomes Machado. S. Paulo: Nova Cultural, 1999d. (Coleção Os Pensadores; Vol. I). 
. "Júlia ou a Nova Heloísa”. Trad. Fúlvia M. L. Moretto. 2a ed. São Paulo: Hucitec, 2006.

SALINAS FORTES, L. R. "Paradoxo do espetáculo: política e poética em Rousseau”. São Paulo: Discurso Editorial, 1997.

STAROBINKSI, J. "As máscaras da civilização: ensaios". Trad. Maria Lúcia Machado. São Paulo: Companhia das Letras, 2001.

VOLTAIRE. "Contos". Trad. Roberto Domênico Proença. São Paulo: Nova Cultural, 2003. 